\title{
New data on the European species of three genera Scelionidae (Hymenoptera)
}

\author{
BERNARD PINTUREAU* \& MOUNIR AL-NABHAN** \\ *Biologie fonctionnelle, Insectes et Interactions - UMR INRA/INSA de Lyon, INSA Bâtiment L. Pasteur, \\ 69621-Villeurbanne-cedex, France. Author to whom correspondence and offprint requests should be \\ addressed.E-mail: pinture@jouy.inra.fr \\ **Aleppo University, Agricultural Faculty, Aleppo, Syria.E-mail: malnabhan1@hotmail.com
}

\begin{abstract}
Among the Scelionidae recently collected in several countries, mainly from Europe, the genus Gryon was represented by two species, the genus Baeus by one species and the genus Idris by three species. Four species are reported as new for France (two species of Gryon, one of Baeus and one of Idris), three as new for for Portugal (Azores) (one species of each of the three studied genera) and one as new for Syria (one species of Gryon). Improved morphological descriptions with illustrations are provided for several of the species. A new host (eggs of the pentatomid bug Eurygaster integriceps) is recorded for Gryon fasciatus Priesner.
\end{abstract}

Key words: Baeini, egg parasitoid, France, Gryonini, Ireland, Portugal, Scelioninae, Syria, systematics

\section{Introduction}

The family Scelionidae, belonging traditionally to the Proctrotrupoidea superfamily (or more recently to Scelionoidea according to Masner, 1956; or Platygastroidea according to Naumann, 1991), includes only egg parasitoids of numerous groups of insects and spiders. New material of that family was recently collected in some European countries, especially France, and in Syria. Most of the collections were carried out by means of yellow pan traps containing water and a wetting agent.

Genera were determined using Masner's keys $(1976,1980)$ and Kozlov's key (1988). The chosen divisions into subfamilies and tribes are those considered by Austin and Field (1997). Among the numerous genera recognized in the subfamily Scelioninae, three are studied in the present paper: Gryon Haliday, Baeus Haliday and Idris Foerster. The studied material allows the addition of several new species to the French, Portuguese (Azorean) 
and Syrian faunas, and to improve our knowledge of the biodiversity in these countries. It also allows an improved description of some morphological characters.

\section{Tribe Gryonini}

\section{Gryon Haliday}

Masner (1976, 1983) and Mineo (1991) listed several synonyms: Acolus Foerster, Austroscelio Dodd, Eremioscelio Priesner, Exon Masner, Hadronotellus Kieffer, Hadronotus Foerster, Hadrophanurus Kieffer, Heterogryon Kieffer, Holacolus Kieffer, Masneria Szabó, Muscidea Motschulski, Notilena Brèthes, Pannongryon Szabó, Plastogryon Kieffer, Plesiobaeus Kieffer, Psilacolus Kieffer, Sundholmia Szabó, Synteleia Fouts, Telenomoides Dodd. However, Austin and Field (1997) maintained Eremioscelio, Plesiobaeus and Sundholmia as distinct genera.

\section{Species of the misellum group (Masner 1983)}

\section{Gryon misellum Haliday}

Masner $(1976,1983)$ listed basalis Thomson, bicolor Ashmead, brevipennis Kieffer, foersteri Kieffer, investis Kieffer, opacus Thomson, pumilio Nees, sagax Kieffer and walkeri Kieffer as synonyms.

Material examined. One female collected by sweeping at Furnas, Island of S. Miguel, Azores, Portugal, on 14 July 1989; four females and 3 males collected in yellow pan traps: 3 females (1 female on 7 August 1991, 1 female on 8 August 1991 and 1 female on 10 September 1991) and 3 males (1 male on 28 June 1991, 1 male on 4 July 1991 and 1 male on 6 August 1991) at Vénissieux, Rhône, France; 1 female at Hog's Head, Waterville, Kerry, Ireland, on 13 July 1994.

The species has been recorded previously from the following North American, Australasian and European countries: Albania, Australia, Bosnia-Herzegovina, Bulgaria, Canada, former Czechoslovakia, Finland, Great Britain, Greece, Hungary, Moldavia and Russia (Szabó 1966; Hellén 1971; Kozlov 1971, 1988; Masner 1983; Mineo 1989). Therefore, it is new for Portugal (Azores) and France. Hosts are unknown.

FIGURE 1. Gryon misellum, different sizes of wings in French individuals from Vénissieux. A, B and D: forewings and hind wings of three females; C: forewing of a male; $\mathrm{E}$ and F: forewings and hind wings of two males. Bar scale: $0.1 \mathrm{~mm}$. 

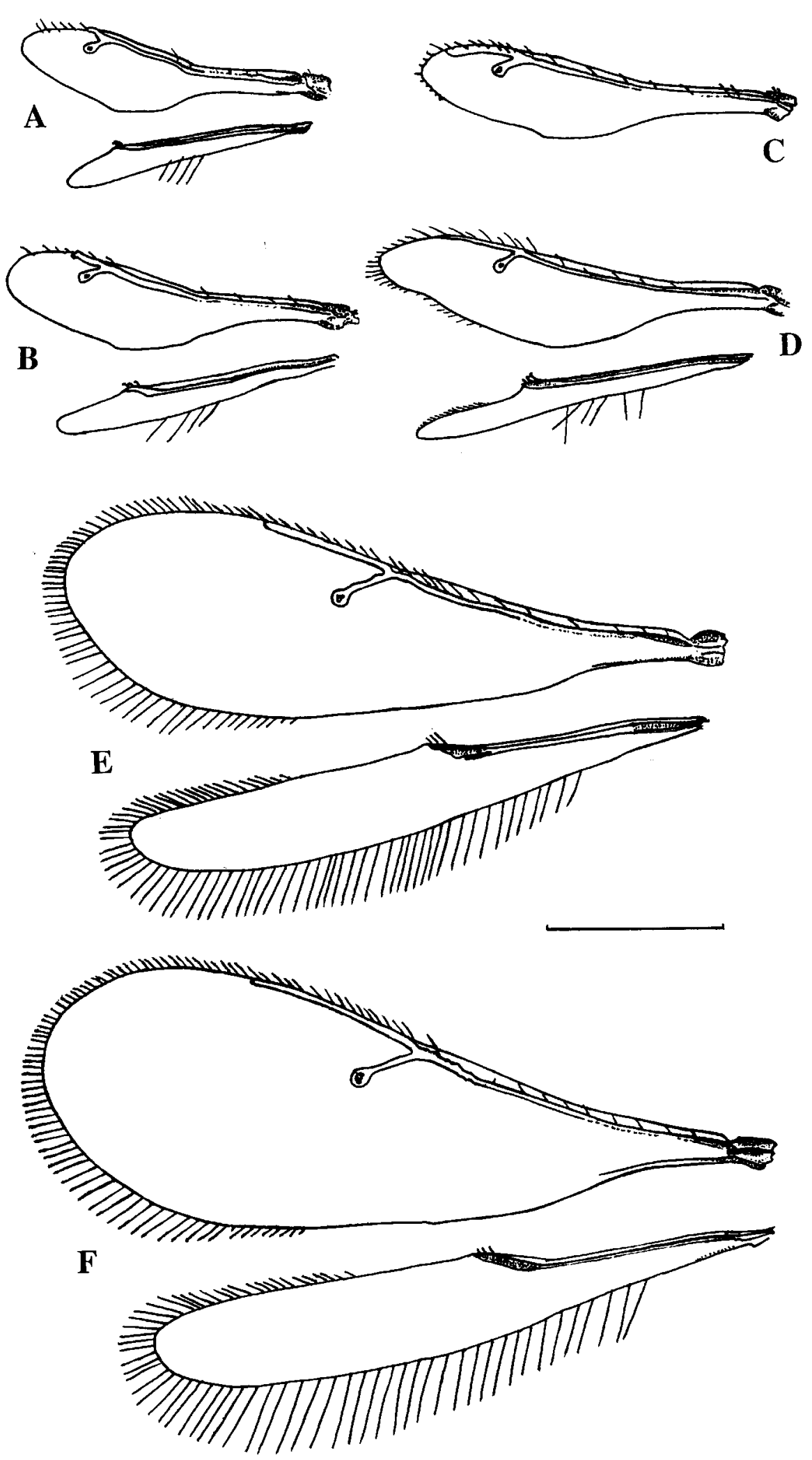
Morphology. The species was redescribed by Masner (1961). Kozlov (1988), Kozlov and Kononova (1990) and Kononova (1992) illustrated male and female antennae and hind wing. Individuals (males and females) are often brachypterous. While the two collected females from Azores and Ireland showed normal wings, the three French females were brachypterous (Fig. 1A, B, D) and two out of the three French males were brachypterous (Fig. 1C, E). The normal wings of the third French male appear in figure 1F.

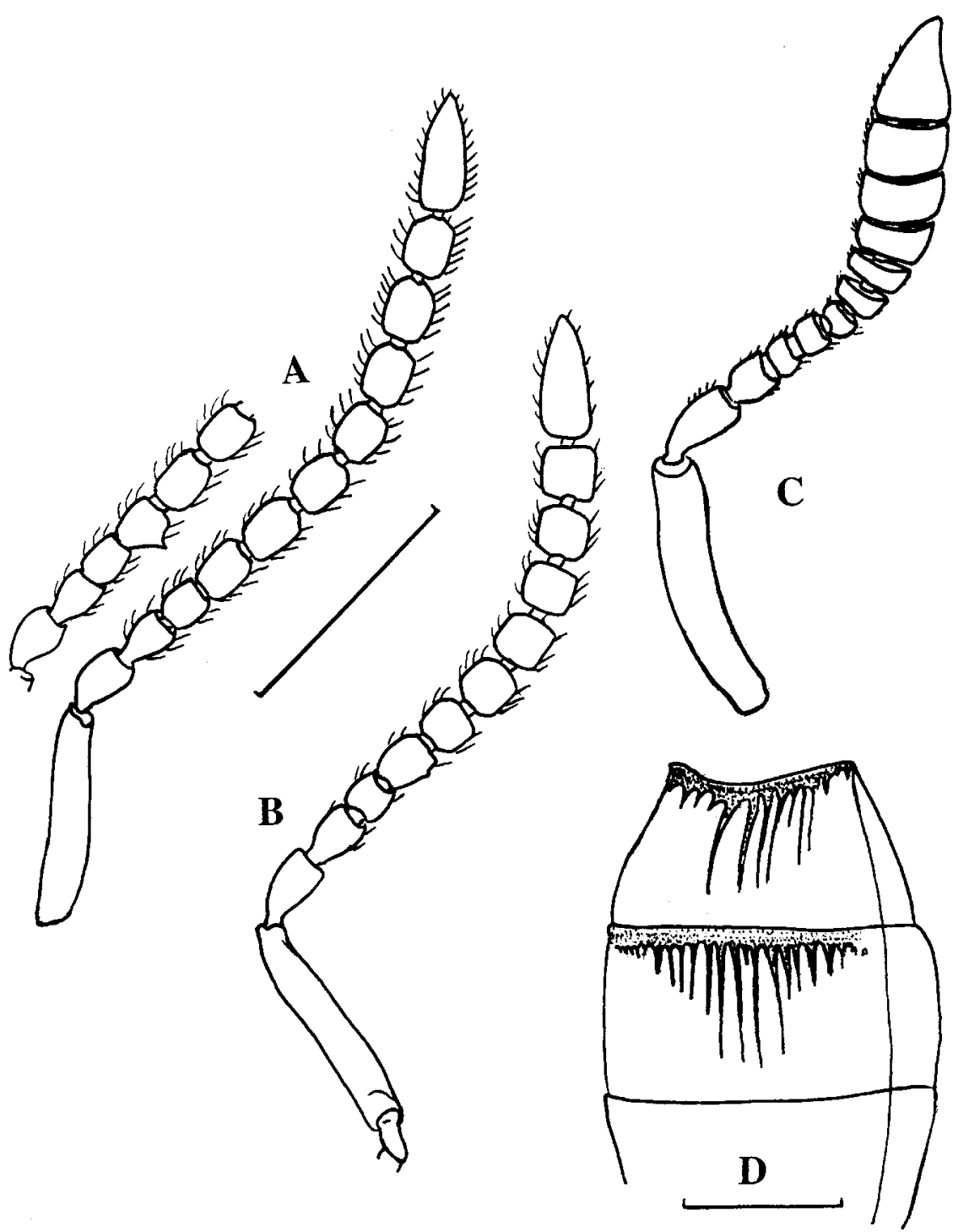

FIGURE 2. Gryon misellum, French individuals from Vénissieux. A and B: male antennae in two individuals showing some variation (A is represented in two positions to better illustrate the shape of the fifth segment); C: female antenna; D: anterior part of the male abdomen in dorsal view. Bar scale: $0.1 \mathrm{~mm}$. 
Variations in male antennae were recorded in the French population (Fig. 2A, B), the funicular segments being more or less elongated as illustrated to originally distinguish between the two now synonymous species G. misellum and G. investis (Kozlov \& Kononova 1990; Kononova 1992). The female antenna and male genitalia appear in figures $2 \mathrm{C}$ and 3A, respectively. Abdominal sculpture is variable in the species (Mineo 1980; Masner 1983) and a French male abdomen was thus also figured (Fig. 2D).

A

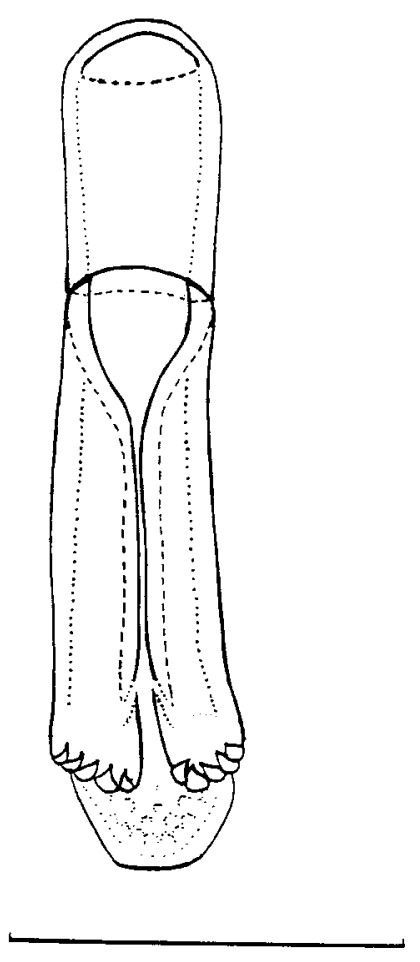

B

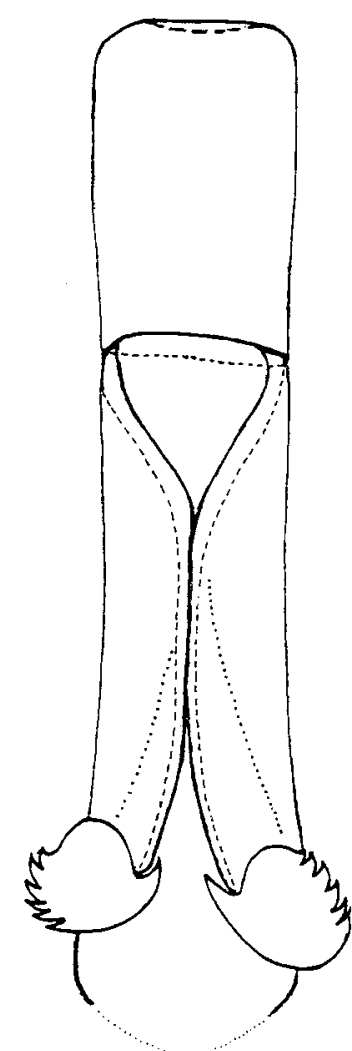

FIGURE 3. Male genitalia of Gryon. A: G. misellum; B: G. fasciatus. Bar scale: $0.05 \mathrm{~mm}$.

\section{Species of the myrmecophilum group (Mineo 1991)}

\section{Gryon fasciatus Priesner}

Material examined. One male collected in a yellow pan trap at Vénissieux, Rhône, France, on 25 July 1991. One male collected at Hasaké, Syria, on May 1998, in Eurygaster integriceps eggs (Het.: Pentatomidae) laid on wheat (material sent by A. Babi). 
The species has previously been recorded from some African and eastern European countries: Egypt, Moldavia, Russia, Somalia, Ukraine, Zaire, Zimbabwue (Kozlov 1971, 1988; Kozlov \& Kononova 1990; Mineo 1991; Kononova 1992, 1994). Therefore, it is new for France, and for Syria and the Middle East. Eggs of E. integriceps are the first known hosts.

Morphology. Kozlov and Kononova (1990), Mineo (1991) and Kononova (1992) redescribed the species and illustrated male and female antennae and wings. The male genitalia appear in figure 3B.

\section{Tribe Baeini}

Kozlov and Konova (1990) did not include the tribe Baeini in the subfamily Scelioninae, but instead in the Baeinae.

\section{Baeus Haliday}

Kozlov $(1971,1988)$ noted Hyperbaeus Foerster as a synonym.

\section{Baeus seminulum Haliday}

Material examined. Eighteen females and 3 males collected in yellow pan traps: 14 females (2 females on 6 August 1991, 1 female on 22 September 1991, 1 female on 26 September 1991, 1 female on 1 October 1991, 1 female on 16 October 1991, 2 females on 29 October 1991, 2 females on 30 October 1991, 3 females on 1 November 1991 and 1 female on 9 November 1991) and 2 males (1 male on 10 August 1991 and 1 male on 22 September 1991) at Vénissieux, Rhône, France; 1 female (3 November 1991) at Monsols, Rhône, France; 3 females (1 female on 16 August 1993, 1 female on 28 August 1993 and 1 female on 1 September 1993) at Masseube, Gers, France; 1 male (27 August 1991) at Remédios, Island of S. Miguel, Azores, Portugal. The latter male was misidentified as Idris sp. by Pintureau and Pintureau (1996).

The species has previously been recorded from several European countries: Austria, Belgium, Denmark, Finland, Germany, Great Britain, Italy, Moldavia and Russia (Debauche 1947; Hellén 1971; Kozlov 1971, 1988; Mineo 1979; Rollard 1991; Kononova \& Fursov 1999). Therefore, it is new for France and Portugal (Azores). Its known hosts are spider eggs, especially of the families Argiopidae and Theridiidae, Rollard (1991) cited Coelotus terrestris Wid., Dysdera erythrina Walker, Micryphantes sp., Tegenaria picta Sim. and Theridium sp.

FIGURE 4. Baeus seminulum, male. A: forewing; B: hind wing; C: antenna; D: anterior part of the abdomen in ventral view; E: genitalia. Bar scale: $0.1 \mathrm{~mm}(\mathrm{~A}, \mathrm{~B}, \mathrm{C}$ and D) or $0.05 \mathrm{~mm}(\mathrm{E})$. 


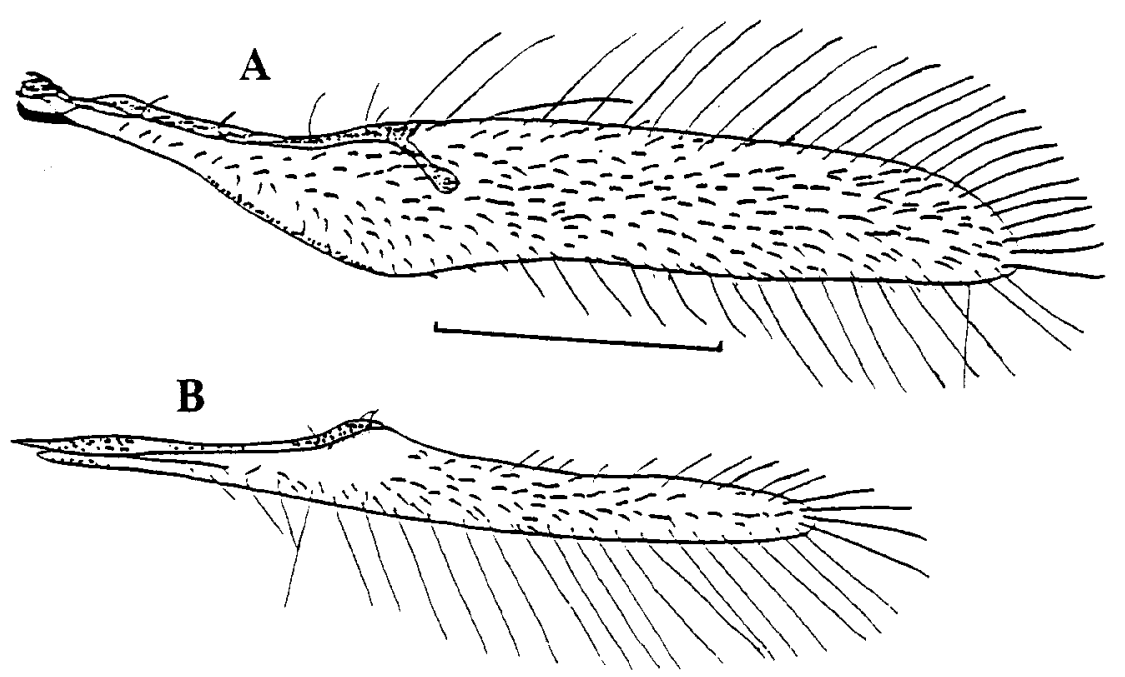

ZOOTAXA
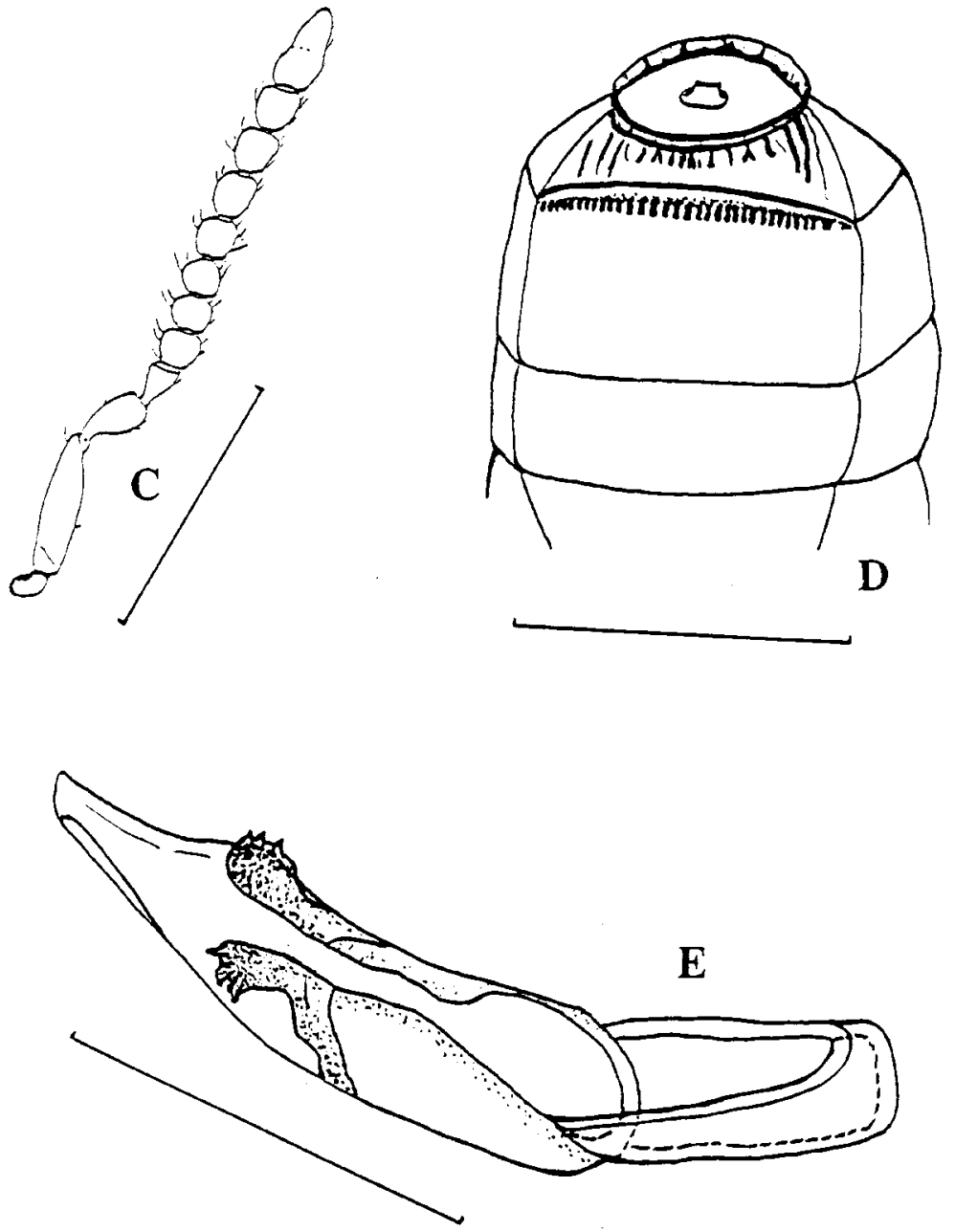
Morphology. The female has been redescribed and well illustrated (Kozlov 1988; Kononova \& Fursov 1999). On the contrary, male morphology has yet to be described and is provided here. Wings are narrow with long marginal setae (Fig. 4A, B), forewing 6.5 times as long as the maximum width with longest marginal setae almost as long as the maximum wing width, hind wing 8.5 times as long as the maximum width with longest marginal setae 1.6 times as long as the maximum wing width. Kozlov $(1971,1988)$ illustrated the forewing, but his drawing is erroneous: the wing is too wide (4.5 times as long as the maximum width) and has marginal setae that are too short (the longest 0.6 times as long as the maximum wing width). Antennae with 11 free segments; the 7 funicular segments are subequal and the last segment shows an indistinct suture in its middle (Fig. 4C). Abdominal T1 and T2 have numerous ridges, close to each other on T2 (Fig. 4D). Genitalia have well developed digiti (Fig. 4E). These males appear closely related to those of $B$. japonicus Kononova and Fursov; that species, however, shows slightly narrower forewing (6.6 times as long as the maximum width) with longer marginal setae (longest 1.3 times as long as the maximum wing width).

\section{Idris Foerster}

Kozlov and Kononova (1990) included the genus Idris in the tribe Idrini of the subfamily Baeinae. Huggert (1979) and Masner and Denis (1996) listed several synonyms: Acoloides Howard, Ceratobaeus Ashmead, Megacolus Priesner, Philoplanus Muesebeck and Walkley, Pseudobaeus Perkins, Tasmanacolus Hickman, Tasmanibaeus Hickman. However, Austin and Field (1997) maintained Ceratobaeus as a distinct genus.

\section{Species of the piceiventris group (Huggert 1979)}

\section{Idris nigroclavatus (Kieffer)}

Huggert (1979) listed coxalis Kieffer and striativentris Kieffer as synonyms.

Material examined. Two females collected by sifting of deadwood at Sainte-Foy-lesLyon, Rhône, France, in December 1992 (material collected by R. Allemand).

The species has previously been recorded from several European countries: Austria, Bosnia-Herzegovina, Croatia, France, Hungary, Italy, Moldavia, Spain, Sweden and Ukraine (Kozlov 1971, 1988; Huggert 1979). In France, it was previously only known from Haute-Savoie, therefore it is new for the Rhône département. Hosts are unknown, but are probably spider eggs.

Morphology. Szabó (1965) redescribed I. coxalis, and Huggert (1979) more accurately redescribed and illustrated the species. 
Huggert (1979) listed aureopetiolatus Ogloblin and cernosvitovi Ogloblin as synonyms.

Material examined. One female collected in a yellow pan trap at Vénissieux, Rhône, France, on 6 August 1991.

The species has been recorded from several European countries: Austria, Croatia, former Czechoslovakia, Finland, Germany, Greece, Hungary, Italy, Moldavia, Sweden, Switzerland and Ukraine (Kozlov 1971, 1988; Huggert 1979). Therefore, it is new for France. Hosts are spider eggs, probably such as Meta segmentata (Clerck) (Huggert 1979).

Morphology. Kozlov (1971) illustrated I. aureopetiolatus, and Huggert (1979) more accurately redescribed and illustrated the species.

\section{Species of the rufescens group (Huggert 1979)}

\section{Idris rufescens (Kieffer)}

Huggert (1979) listed adejensis Huggert, flavicornis Kieffer and kiefferi Masner as synonyms.

Material examined. Two females collected in a yellow pan trap at Remédios, Island of S. Miguel, Azores, Portugal, on 1 September 1991.

The species has previously been recorded from several European countries: Austria, Bulgaria, Croatia, France, Hungary, Italy, Spain (including the Canary Islands) and Sweden (Huggert 1979). Therefore, it is new for Portugal (Azores). Hosts are unknown, but probably spider eggs.

Morphology. The species was redescribed and illustrated by Huggert (1979) who recognized several forms: most specimens, especially those from south Europe, are blackish with a paler abdomen, specimens from Sweden and some specimens from Hungary are brownish with a reddish abdomen, while specimens from the Canary Islands are more shiny and show broader wings with infumation. Females from Azores are brownish with paler head, antennae (except scapes) and legs, and look like the Canary Islands form. The forewing (Fig. 5A) and the hind wing (Fig. 5B) are broader (width/length or W/L=0.38 and 0.23 , respectively) than in the Huggert (1979)'s specimen (W/L=0.34 and 0.18 , respectively). The antenna (Fig. 5C) shows a longer pedicel and first funicular segment (L/ scape length $=0.54$ and 0.29 , respectively) than in the Huggert (1979)'s specimen ( 0.38 and 0.18 , respectively). The abdomen (Fig. 5D) seems less broad (W/L=0.77) than in the Huggert (1979)'s specimen (W/L=0.80).

FIGURE 5. Idris rufescens, female. A: forewing; B: hind wing; C: antenna; D: abdomen in ventral view. Bar scale: $0.1 \mathrm{~mm}$. 

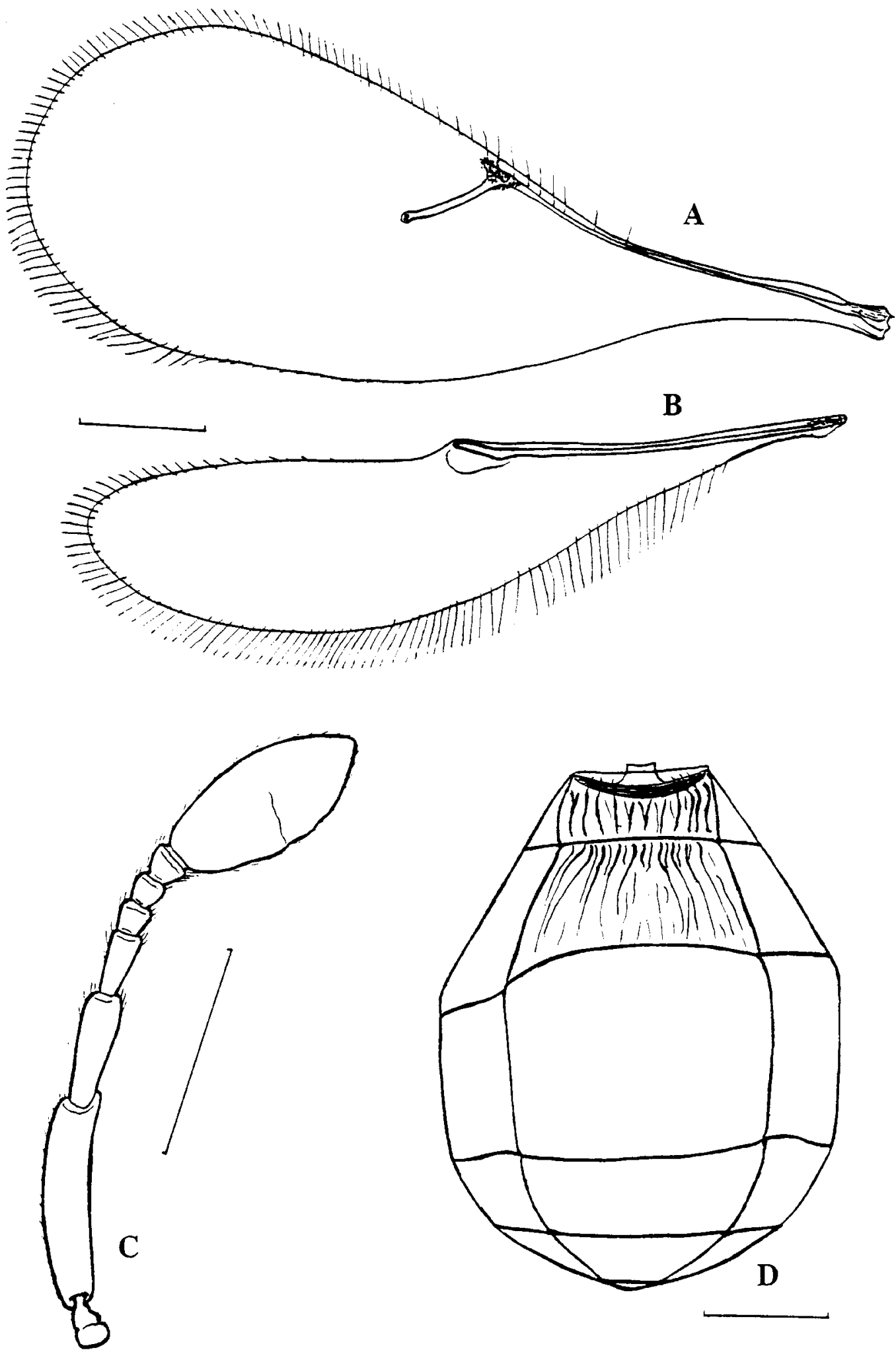
S.V. Kononova (Institute of Zoology, Kiev, Ukraine) determined the species Gryon fasciatus (Syrian individual). P. Bolland (UMR BF2I, Villeurbanne) contributed to the figures.

\section{References}

Austin, A.D. \& Field, S.A. (1997) The ovipositor system of Scelionid and Platygastrid wasps (Hymenoptera: Platygastroidea): comparative morphology and phylogenetic implications. Invertebrate Taxonomy, 11, 1-87.

Debauche, H.R. (1947) Scelionidae de la faune belge (Hymenoptera Parasitica). Bulletin Annuel de la Société Entomologique de Belgique, 83, 255-285.

Hellén, W. (1971) Die Scelioninen Finnlands (Hymenoptera: Proctotrupoidea). Fauna Fennica, 23, $1-25$.

Huggert, L. (1979) Revision of the west palaearctic species of the genus Idris Förster s.l. (Hymenoptera, Proctotrupoidea: Scelionidae). Entomologica Scandinavica, 12 (suppl.), 1-60.

Kononova, S.V. (1992) Ukrainian fauna, XI: hymenopteran parasitoids, part 10, Acad. Sc. Ukraine (Ed), Kiev, Naukova Publ., 253 pp.

Kononova, S.V. (1994) Additional records to the fauna of Scelionidae (Hymenoptera) from the Tchita Region. In: Dahuria National Park (Ed) Insects from the National Park of Dahuria and adjacent territories, pp. 124-135.

Kononova, S.V. \& Fursov, V.N. (1999) A review of palaearctic species from the genus Baeus (Scelionidae, Baeini)-egg parasites of spiders (Arachnida). Zoological Journal, 78, 1284-1291.

Kozlov, M.A. (1971) Proctotrupoids (Hymenoptera, Proctrotrupoidea) of the USSR. Horae Societatis Entomologicae Unionis Soveticae, 54, 3-67.

Kozlov, M.A. (1988) Family Scelionidae (Scelionids). In: Medvedev, G.S. (Ed) Keys to the Insects of the European part of the USSR, III: Hymenoptera, part II, E.J. Brill, Leiden (The Netherlands), pp. 1110-1179.

Kozlov, M.A. \& Kononova, S.V. (1990) Hymenoptera, Scelionidae, Scelioninae from USSR, Acad. Sc. USSR (Ed), Leningrad, Nauka Publ., 344 pp.

Masner, L. (1956) First preliminary report on the occurrence of genera of the group Proctotrupoidea (Hymenoptera) in CRS (first part-family Scelionidae). Acta Faunistica Entomologica Musei Nationalis Prague, 1, 99-126.

Masner, L. (1961) The genera Gryon Hal., Idris Foerst. and Hemisius Westw. (Hym. Scelionidae). Acta Societatis Entomologica Cechosloveniae, 58, 157-168.

Masner, L. (1976) Revisionary notes and keys to world genera of Scelionidae (Hymenoptera: Proctotrupoidea). Memoirs of the Entomological Society of Canada, 97, 1-87.

Masner, L. (1980) Key to genera of Scelionidae of the holarctic region, with descriptions of new genera and species (Hymenoptera: Proctotrupoidea). Memoirs of the Entomological Society of Canada, 113, 1-54.

Masner, L. (1983) A revision of Gryon Haliday in North America (Hymenoptera: Proctotrupoidea: Scelionidae). The Canadian Entomologist, 115, 123-174.

Masner, L. \& Denis, J. (1996) The nearctic species of Idris Foerster. Part I: the melleus-group (Hymenoptera: Scelionidae). The Canadian Entomologist, 128, 85-114.

Mineo, G. (1979) Studies on the Scelionidae (Hym. Proctotrupoidea). IX. Material for a revision of the genus Gryon Hal., with description of 4 new species (G. austrafricanum, G. eremiogryon, G. laraichii, G. nicolai) and notes on other Scelionids. Bollettino del Laboratorio di Entomologia Agraria "Filippo Silvestri", 36, 234-265. 
Mineo, G. (1980) Studi sugli Scelionidae (Hym. Proctotrupoidea). X. Materiale per una revisione del genere Gryon Haliday: osservazioni su specie note, nuove sinonimie e descrizione del maschio di Gryon dichropterus Kozlov. Bollettino dell' Istituto di Entomologia agraria dell' Osservatorio di Fitopatologia di Palermo, 10, 189-203.

Mineo, G. (1989) Studies on the Scelionidae (Hym., Proctotrupoidea). XXVI. Material for a revision of Gryon Hal. with description of a new species: Gryon risbeci. Frustula Entomologica, $12,47-59$.

Mineo, G. (1991) Description of new species of Gryon Haliday (Hym., Scelionidae). Frustula Entomologica, 14, 1-42.

Naumann, I.D. (1991) Hymenoptera. In: The Insects of Australia, $2^{\text {nd }}$ Ed., Melbourne University Press and CSIRO, Melbourne, pp. 916-1000.

Pintureau, M. \& Pintureau, B. (1996) Les Scelionidae de l'archipel des Açores (Hymenoptera). Relatórios e Comunicações do Departamento de Biologia, 23, 51-53.

Rollard, C. (1991) Révision des Insectes consommateurs d'œufs d'Araignées. I.-Les Hyménoptères. Bulletin de la Société Entomologique de Mulhouse, 49-61.

Szabó, J.B. (1965) Remarks on the systematics of the genus Idris Förster, 1856, with redescription of Idris coxalis Kieffer, 1908, and description of some new palaearctic species (Hymenoptera, Scelionidae). Annales Historico-Naturales Musei Nationalis Hungarici, Pars Zoologica, 57, $367-373$.

Szabó, J.B. (1966) Ökologische; ethologische, tiergeographische und systematische untersuchungen an paläarktischen gryoninen (Hymenoptera: Proctotrupoidea, Scelionidae). Acta Zoologica Academiae Scientiarum Hungaricae, 12, 419-449. 